\title{
Environmental Education Organizations and Programs in Texas: Identifying Patterns through a Database and Survey Approach for Establishing Frameworks for Assessment and Progress
}

\author{
Jenny D. Lloyd-Strovas ${ }^{1,2, *} \&$ Thomas L. Arsuffi ${ }^{1}$ \\ ${ }^{1}$ Llano River Field Station, Texas Tech University Center at Junction, Junction, TX, USA \\ ${ }^{2}$ Department of Biological Sciences, Texas Tech University, Lubbock, TX, USA \\ *Correspondence: Llano River Field Station, Texas Tech University Center at Junction, Junction, TX, USA. Tel: \\ 1-806-577-9644. E-mail: 1loydstrovas@gmail.com
}

Received: September 28, 2016

Accepted: October 17, $2016 \quad$ Online Published: November 15, 2016

doi:10.5430/wje.v6n6p1

URL: http://dx.doi.org/10.5430/wje.v6n6p1

\begin{abstract}
We examined the diversity of environmental education (EE) in Texas, USA, by developing a framework to assess EE organizations and programs at a large scale: the Environmental Education Database of Organizations and Programs (EEDOP). This framework consisted of the following characteristics: organization/visitor demographics, pedagogy/curriculum, operations, and assessment. A database of organizations was built by surveying EE program directors state-wide. Of 237 possible organizations, 82 responded to the survey. Results showed that $6-20 \%$ of Texans are exposed to EE yearly. In 2009, each of these organizations conducted 19 programs to serve 6,000 people using only $\$ 7,500$ USD (based on medians). Environmental educators most frequently used hands-on, outdoor experiments and group discussions to teach students, suggesting constructivism as the underlying learning theory in Texas EE. The field needs a comprehensive analysis of the large diversity of organizations and programs to better understand the structure and function of EE. Databases are highly effective tools in education research because they provide: 1) a source of quality research; 2) information across multiple scales; 3) networking and collaboration; and 4) comprehensive and longitudinal data for testing theories. This study provides a framework for creating large-scale databases of EE organizations and identifies patterns among and between characteristics.
\end{abstract}

Keywords: organization characteristics; pedagogy; outdoors; demographics; database; assessment

\section{Introduction}

Databases have been used to advance many disciplines. Medicine has used databases to build knowledge on genetic patterns which cause human disease and illness, e.g., the Serial Analysis of Gene Expression database for cancer research (Lal et al., 1999) and the Structural Database of Allergen Proteins for allergy research (Mari, 2005). Ecology has used databases to record and compare ecological processes over extensive temporal and spatial scales, e.g., the Long-Term Ecological Research Network Information System (Baker et al., 2000) and the Global Population Dynamics Database (Inchausti \& Halley, 2001). Education in the United States (U.S.) has also used databases to keep track of K-12 public schools (National Center for Education Statistics-Common Core of Data, n.d.) and universities (US Department of Education-The Database of Accredited Postsecondary Institutions and Programs, 2013).

Databases are vital for large-scale, data intensive and extensive, research because they provide a tool for collecting and managing information which can lead to new insights and knowledge (Becerra-Fernandez \& Leidner, 2008). Databases develop new knowledge by providing: 1) a source of high quality research, 2) an efficient conduit in which individuals and organizations can network and collaborate (Franklin et al., 1990), 3) information at multiple scales temporal and spatial (Baker et al., 2000), and 4) comprehensive and longitudinal data for testing theories (Franklin et al., 1990).

Databases provide one method for advancing EE research by identifying structure and patterns within this diverse 
discipline. A few states in the U.S. have used databases to provide online tools for practitioners and community members to search for EE programs in their region (Illinois Environmental Education Database, 2003; Arizona Association for Environmental Education, 2010; Environmental Education in Alabama, n.d.; North Carolina Environmental Education, n.d.). Much like a telephone book, these databases are largely used as a guide for providing lists of programs and locations. However, a database intended for research would be able to address questions related to the complex structure of $\mathrm{EE}$ and better explain functional patterns within the field.

Environmental education in Texas is highly complex because of the state's large geographic size and diversity in terms of bioregions, demographics, formal/informal programming, cultures, and flora and fauna. Texas is ranked second in the nation for land size (National Atlas, 2013), population size (U.S. Census Bureau, 2010), and the number of plant and animal species (Stein, 2002). This natural and cultural diversity provides great challenges because of the large quantity and diversity of organizations which implement EE in the state. Databases provide a tool to reduce this complexity by managing and simplifying this complex information into structural and functional properties of EE at multiple scales.

Kirk et al. (1997) and Ruskey et al. (2001) used a database approach to address state-level EE in the United States and their results may explain why Texas EE has not made as much progress as other states. Texas is behind other states in the following areas: formal EE learning objectives/assessment tools, a grant program, and regional/state-wide EE offices. Bergeson et al. (2007) conducted empirical studies that showed academic achievement across many disciplines (e.g., science, math, social studies) in Washington because of EE initiatives like state-wide infrastructure in which EE is incorporated within formal education standards.

The databases currently available in EE are primarily used to identify curricula or locate venues for environmental learning. The Environmental Education Database of Organizations and Programs (EEDOP) was designed to advance research in this discipline by identifying structural and functional properties of EE in Texas. This study provides a framework for recording the diversity of EE in Texas, identifies patterns among organization characteristics, suggests factors which may underlie these patterns, and provides a direction for advancement of the field. EEDOP differs from Kirk et al. (1997) and Ruskey et al. (2001) by focusing on individual organizations and program characteristics; yet, it builds on their work by adding another level to EE database research. This is the first comprehensive database analysis of EE organizations and programs in Texas, and possibly, the nation. EEDOP provides a research-based framework that can be applied internationally by adapting parameters to fit individual regions and countries. This database and resulting comparisons addressed a number of factors regarding EE in Texas but can be applied to EE in any region. Research questions (RQ\#) 1-4 address the structural characteristics of EE organizations and programs and RQ\#5 identifies functional patterns among those characteristics. The RQs are as follows:

1. What are the demographic characteristics of Texas EE programs and their visitors?

2. What curricula and pedagogical characteristics are most common among Texas EE programs?

3. What are the basic operational characteristics of Texas EE programs?

4. Are Texas EE programs being assessed? How?

5. Are there relationships among program characteristics?

\section{Methods}

A comprehensive database of Texas organizations that conduct EE programs was generated through four stages: 1) identifying attributes of EE organizations and programs for study, 2) organizing attributes in a survey to collect data, 3) compiling a list of currently operating EE organizations in the state and surveying them, and 4) analyzing responses to identify patterns. Each stage is described below.

\subsection{Attributes of Environmental Education Organizations and Programs}

Important attributes of EE organizations were identified through three methods: 1) a review of relevant literature (Niedermeyer, 1992; Kirk et al., 1997; Ruskey et al., 2001), 2) a review of guidelines for EE (NAAEE, 2004 \& 2007), and 3) a review of websites of established EE organizations in Texas ( $n=10)$. After these reviews, the following attributes were included in this study: organization and visitor demographics (based on the reviews of literature, guidelines, and websites), pedagogy and curriculum (literature, guidelines, websites), operations (websites), and assessment (literature, guidelines). All attributes and their respective components are briefly described below. 


\subsubsection{Organization and Visitor Demographics}

This attribute refers to characteristics used to describe organizations that conduct EE programs and the people that participate in them. Organization demographic components included organization type, ecological region, annual visitation, and funding. Visitor demographic components included age, gender, race/ethnicity, and socio-economic grouping. The term 'visitors' refers to a person who would use the services offered by the organization: those who visit the organization's facilities (e.g., people who walk an interpretive trail), and those who used their programming services (e.g., elementary students who spend a day at a nature center studying the water cycle). Organizations were asked to report relative frequencies (percentages) concerning all visitor demographic information. Since most organizations do not keep detailed records of these characteristics, percentages were the most appropriate parameter for reporting this data.

To estimate the exposure of Texans to EE, we used the median, mean, and sum from the following demographic variables: number of Texans educated by EE organizations per year, cost per visitor, and number of K-12 students served. The top two extreme outliers were removed for the estimated calculations to provide a more realistic range of values - most parameters were largely skewed because a few organizations operated at a high capacity. The percentage of Texans exposed to EE yearly was estimated by: 1) multiplying the median annual visitation by 237 (number of EE organizations identified) and dividing the product by the state population size (25 145561 - based on the U.S. Census Bureau, 2010); 2) using same calculation for the mean; and 3) summing the annual visitation for all responding organizations and multiplying that number by three (because $35 \%$ of the 237 organizations participated in the study), then dividing it by the state population size. Similarly, we estimated the amount of money spent per visitor for EE in Texas by: 1) the median budget divided by the median annual visitation; 2) the mean budget divided by the mean annual visitation; and 3 ) the total funding sum divided by the total annual visitation sum from all responding organizations $(\mathrm{n}=82)$. Lastly, we estimated the number of $\mathrm{K}-12$ students exposed to EE yearly by: 1$)$ multiplying the median annual visitation by 237 , multiplying the product by .45 (the percentage of EE organizations that primarily serve K-12 students), and dividing that product by 4878238 (the number of people between the ages of five and eighteen living in Texas, representing the K-12 population - US Census Bureau, 2010); 2) using the same calculation for the mean; and 3) the annual visitation from all responding organizations was multiplied by three (82 organizations represent $35 \%$ of the estimated population), then by .45 , and the product was divided by the population of K-12 students in the state.

\subsubsection{Pedagogy and Curriculum}

Pedagogy and curriculum components included the number of educational programs, number of outdoor educational programs, formal/informal programming, internal/external curricula, use of active/passive learning strategies, recreational programming, and NAAEE curricula guidelines. Formal programming referred to curricula based on the state's K-12 educational standards (Texas Essential Knowledge and Skills; TEA, 2013), while informal programming referred to any curricula that were not based on state standards and could be used for children, college students, adults, and the general public. Internal curricula incorporated educational materials that were developed within the organization, while external curricula (e.g., Project Wet) were developed by others. Active learning strategies included activities where the student was directly involved in the learning process (e.g. experiments, case studies, cooperative learning, etc.), while passive learning strategies did not incorporate student involvement (e.g. listening to a lecture, reading from a book, etc.). Recreational programming involved all outdoor recreational activities (e.g. hiking, fishing, kayaking, etc.) used in programming. Finally, organizations reported if they were aware that the NAAEE established national guidelines for EE.

\subsubsection{Operations}

Organization operation components included land availability and staffing. Land availability referred to the number of acres each organization used for outdoor programming. Staffing referred to the number of educators used by each organization, if those educators were paid employees or volunteers, and if they were certified Texas teachers.

\subsubsection{Assessment}

Organizations reported if they evaluated the EE experience of visitors who participated in educational programs, how the visitors were assessed (e.g. survey, observation, etc.), and if they kept track of school/classroom state standardized test scores.

\subsection{Survey Instrument and Data Collection}

We developed a survey to measure the various components of these attributes for Texas EE organizations. The survey consisted of 25 items ( 9 organization and visitor demographic items; 10 pedagogy and curriculum items; 3 
operations items; 3 assessment items). The survey instrument was checked for face validity by two state employees and for content validity by four EE experts (an EE practitioner, a college professor, an EE doctoral student, and an EE director for a large organization).

Our target population for this study was EE organizations in Texas - all entities which provide educational programs relating to nature and/or environmental issues. Environmental education is a highly diverse discipline; therefore, we sampled nature centers, state and national parks, museums, arboretums, zoos, river authorities, and youth programs. An email was sent to all Texas organizations, identified through the preliminary environmental organization list, in the fall of 2010 and included a link for the online survey via SurveyMonkey. Directors of these programs were specifically targeted; however, since the survey involved multiple program attributes, they may have involved other employees to adequately answer the questions.

\subsection{Texas EE Organization Database}

To build a database of Texas EE organizations we used a directory, information from Texas organizations, and an exhaustive Google search. First, we organized a list of programs based on Chavez and Herron's (2000) Texas EE directory, using a Google search to determine if each organization was operational. Next, we identified additional organizations by reviewing the following websites: Texas Association for Environmental Education, Informal Science Education Association of Texas, Texas Outdoor Education Association, Texas Parks and Wildlife Department (TPWD), Texas River Authorities, Texas Universities, and the National Park Service. Finally, we conducted a Google search to exhaust any remaining EE programs that might not have been associated with the organizations listed above by using the following key terms in varying combinations: Texas, environment, education, $\mathrm{EE}$, nature center, river authority, informal, formal, outdoor, museum, zoo, wildlife, and garden.

\subsection{Analysis of Responses}

Analyses consisted of basic frequency statistics for each component. Comparisons were made between and within select survey components. Medians were used for comparisons due to inflated averages - results showed large, skewed ranges for most characteristics, further illustrating the diversity of EE. Sample sizes vary for each characteristic because program directors were given the choice to answer or skip questions. This project resulted in a large data set with the potential for multiple analyses. To present the information in an organized and useful fashion, we limit analyses to a priori research questions, recognizing that other types of analyses can be gleaned from the database. Here, we use the database as a tool to reduce complexity of EE (e.g., demographics, programming) in Texas. All analyses were conducted using PAWS Statistics 18 software. Human subjects approval was granted by Texas Tech University's Institutional Review Board (\#502482).

The data was not able to meet the assumptions of parametric analyses; therefore, non-parametric tests were used to make inferences (Siegel 1957). Spearman's rho ( $r s)$ was used to identify relationships among components, while Kruskal-Wallis $(H)$ identified differences among organization type (i.e. private, state, federal, municipal, university, river authority). If significance was found using Kruskal-Wallis, pairwise comparisons between organization type were conducted using Man-Whitney U with Bonferroni correction. All within component comparisons were conducted according to organization type because differences between types of organizations were assumed to be responsible for many of the characteristics studied (e.g. funding, staffing, etc.).

\section{Results and Discussion}

We identified 237 currently operating EE organizations within the state of Texas. Of these organizations, 82 participated in the study ( $35 \%$ response rate). The 237 organizations are but a portion of the organizations that offer EE within the state, e.g, many city departments (e.g. Parks and Recreation) have EE programs that are not listed online and therefore could not be identified. Also, there may be other important organizational attributes that were not identified. This study represents the first attempt to record the diversity of the structure and function of EE in Texas and serves as an important baseline for subsequent studies.

\subsection{RQ\#1. What Are the Demographic Characteristics of Texas EE Programs?}

\subsubsection{Organization Type and Location $(\mathrm{n}=82)$}

Thirty-one percent of responding organizations were run by private agencies (25), $48 \%$ by government agencies (21-state, 9 -federal, and 9 -municipal), $12 \%$ by universities, $7 \%$ by river authorities (6), and $2 \%$ by private camps (2). Most organizations that responded to the survey were located in the Prairie and Lakes region (27\%) or the Gulf Coast region $(20 \%)$, the most densely populated regions in the state. EEDOP can identify regions of a state that are most 
active in EE and the types of programs they conduct.

\subsubsection{Annual Visitation $(\mathrm{n}=76)$}

The 2009 annual visitation for organizations ranged from 200-750 000, with an average of 39417 and a median of 6000 (Figure 1). Three measures were used to extrapolate the percentage of Texans exposed to EE yearly (with extreme outliers removed): 1) the median resulted in $6 \%(6000 \times 237 / 25145561) ; 2)$ the mean resulted in $20 \%(21$ $345 \times 237$ / 25145561$)$; and 3) the annual visitation of all organizations resulted in 19\% (1600 865 x 3 / 25145 561 ). These results represent a range of $6-20 \%$, with two of the measures at the high end of this range suggesting that the actual value may be closer to $20 \%$. For a large and diverse state like Texas, one way of assessing the effectiveness of $\mathrm{EE}$ is to determine the number of people being exposed to educational programs. The Texas population is estimated to double by 2050 (Texas State Data Center, 2012) which will further limit the natural resources required to sustain the rapidly growing population. Therefore, it is vital that we reach more than $20 \%$ of the population. EEDOP can help a region determine the number of people EE impacts.

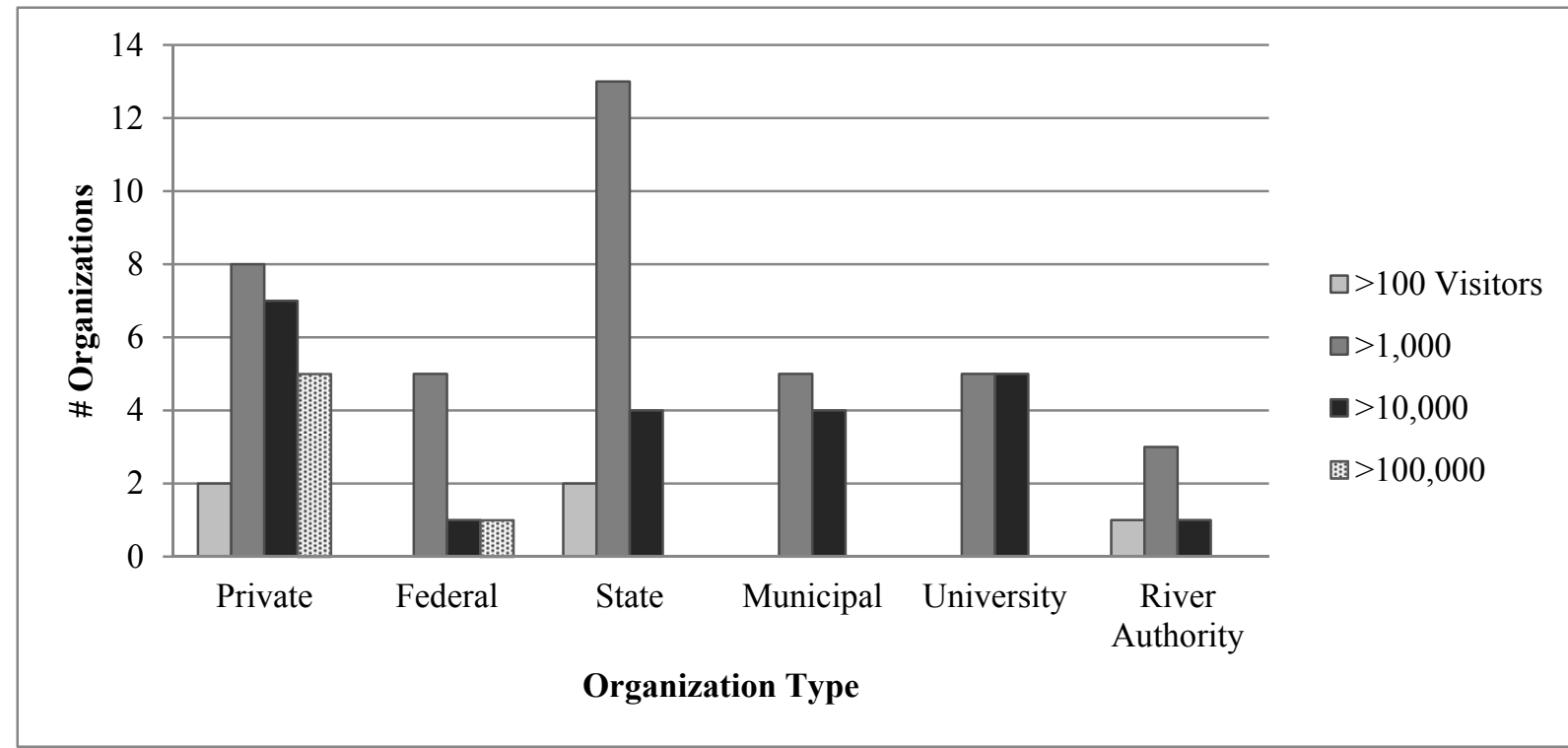

Figure 1. Visitation Rates for Different Types of Texas EE Organizations in 2009

\subsubsection{Organizational Funding $(\mathrm{n}=61)$}

The annual education budget for each organization ranged from $\$ 0-\$ 2000000$ USD, with an average annual budget of $\$ 102870$ and a median of $\$ 7500$ (Figure 2). Three measures were used to extrapolate the amount of money spent per visitor for EE in Texas (with extreme outliers removed): 1) the median resulted in $\$ 1.04 /$ person $(\$ 6250 / 6000) ; 2$ ) the mean resulted in $\$ 4.31$ (\$92 $085 / 21345)$; and 3) the total for all organizations resulted in $\$ 3.45(\$ 5525100 / 1$ 600865 ). These results represent a range of $\$ 1.04-\$ 4.31$, with two of the measures at the high end of this range suggesting that the actual value may be closer to $\$ 4.31$. Organization types had vastly different budgets for education in $2009, H(5,59)=22.85, \mathrm{p}<.001$ (Table 1$)$. Private $(\$ 120 \mathrm{~K})$ and university $(\$ 95 \mathrm{~K})$ organizations had much higher budgets than state organizations $(\$ 1 \mathrm{~K})$. The lack of funding for EE programming has been a serious problem in the past (NEEAC, 1996) and there are several organization types in Texas in which funding remains a serious problem, e.g., state parks. EEDOP provides a tool for monitoring funding rates overtime and could assist with fostering relationships between organizations of unequal funding to develop collaborating programs. 


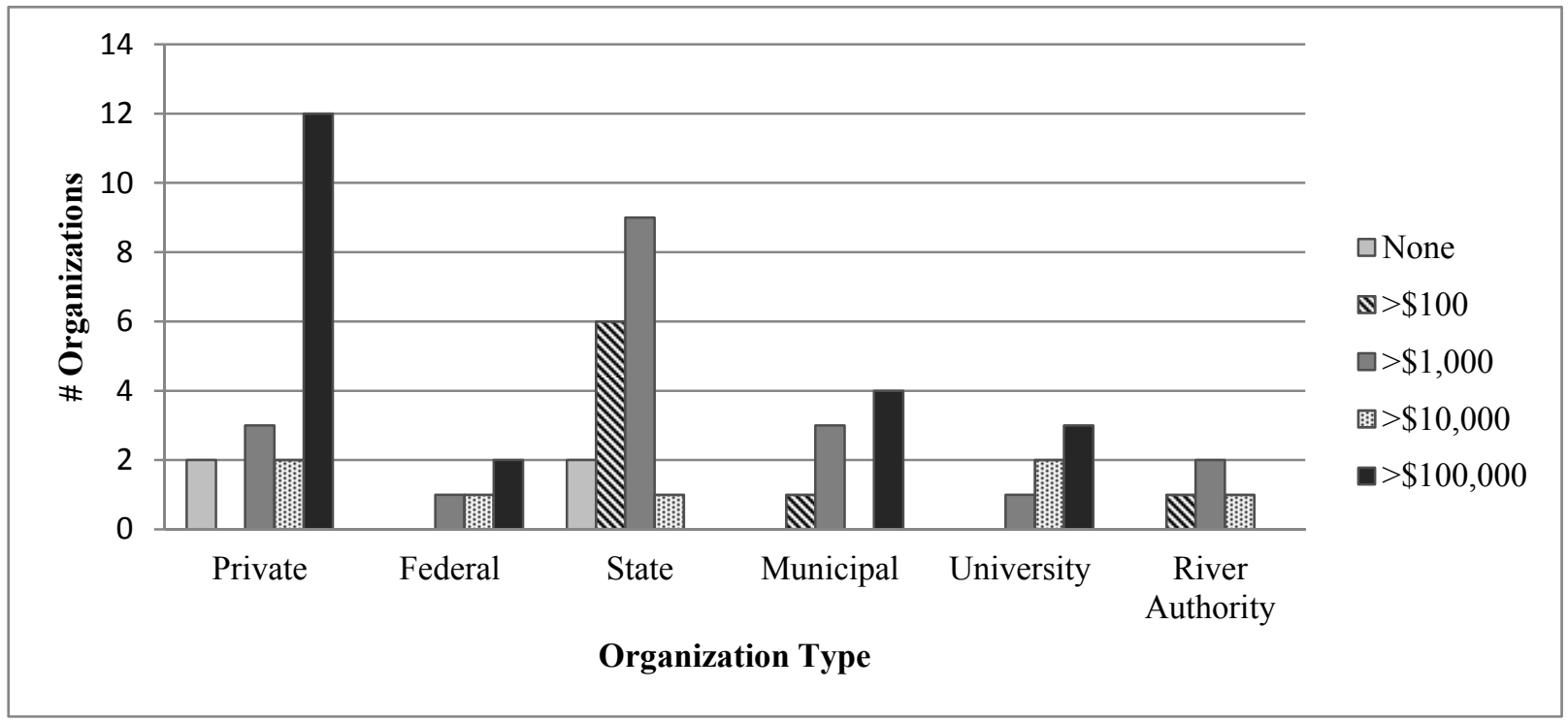

Figure 2. Education Budgets for Different Types of Texas EE Organizations in 2009

Table 1. Differences among Organization Type (i.e. Private, State, Federal, Municipal, University, and River Authority) and Program Characteristics

\begin{tabular}{lcl}
\hline Characteristic & $\begin{array}{c}\text { Difference between } \\
\text { Organization Type }\end{array}$ & Pair-wise Differences (Median) \\
\hline Visitation Rate & \multicolumn{1}{c}{$\mathrm{NS}$} & \\
Funding & $H(5,59)=22.85, \mathrm{p}<.001$ & $\begin{array}{l}\text { Private }(\$ 120 \mathrm{~K}) \& \text { State }(\$ 1 \mathrm{~K}) \\
\text { State }(\$ 1 \mathrm{~K}) \& \text { University }(\$ 95 \mathrm{~K})\end{array}$ \\
Education Programs & $H(5,68)=11.13, \mathrm{p}<.05$ & Private $(30) \&$ University $(15)$ \\
Outdoor Programs & $\mathrm{NS}$ & \\
Acreage & $H(5,62)=20.98, \mathrm{p}<.01$ & Private $(100) \&$ State $(1,038)$ \\
Educators & $H(5,67)=12.76, \mathrm{p}<.05$ & Private $(11) \&$ State $(2)$ \\
\hline
\end{tabular}

NS - Not Significant

\subsubsection{Visitor Age Groups $(\mathrm{n}=69)$}

Thirty-seven organizations (45\%) primarily serve K-12 students. Twenty-seven (33\%) primarily served age groups other than K-12 (i.e. college, adult, general public), and $5(6 \%)$ catered to an equal amount of both age groups. Three measures were used to extrapolate the number of K-12 students exposed to EE yearly (with extreme outliers removed): 1) the median resulted in $13 \%$ ((6000 x 237) x $0.45 / 4878238) ; 2)$ the mean resulted in $47 \%((21345 \mathrm{x}$ 237) $\times 0.45$ / 4878 238); and 3) the total for all organizations resulted in $44 \%$ ((1 $600865 \times 3) \times 0.45 / 4878238)$. These results represent a wide range from $13-47 \%$, with two of the measures at the high end of this range suggesting that the actual value is may be closer to $47 \%$. Coyle (2005) reported that $95 \%$ of Americans support EE in schools, and $85 \%$ agree that government agencies should support the development and implementation of EE. Yet, with only $13-47 \%$ of K-12 students and 6-20\% of the entire state population exposed to EE per year, Texas is not meeting those demands. EEDOP provides a tool for tracking large-scale impact rates for specific populations.

\subsubsection{Visitor Gender, Race/Ethnicity, and Socio-Economic Grouping}

Fourteen organizations reported information on patron gender, while 66 programs indicated that they do not collect this type of data. Of those 14, the proportions of male and female visitors were equally represented. Sixteen programs (5 private, 1 federal, 3 state, 1 university, 1 river authority, 5 municipal) indicated that they primarily served Hispanic and Caucasian populations, while 62 did not collect information on race/ethnicity. Only 10 organizations provided socio-economic information. Five of those organizations reported that most of their visitors 
were considered low income $(<\$ 30 \mathrm{~K} /$ year $)$ and the other five reported to primarily serve middle or high income visitors.

Overall very few organizations collect demographic information on their visitors. This could be due to a lack of resources or appreciation for this data. The NEEAC (1996) argued that important audiences were not being adequately reached by EE (e.g., low-income populations, non- English speakers). For example, of the few organizations that collected information on race/ethnicity, most were private $(n=5)$. Perhaps this is because many private organizations operate on grants which require reporting this type of information.

Knowing the current demographics of a program is important for forecasting future demographic rates. The Texas population is estimated to double by 2050 (Texas State Data Center, 2012), most of who will be Hispanic and living in urban areas. To prepare for these changes in demographics, organizations need to make collecting information on race/ethnicity, socio-economic status, and gender a priority. The National Park Service determined a few methods for forecasting demographics rates: geographic information systems, trend line extensions, and Delphi panels (Gramann, 2003). EEDOP allows organizations the ability to provide quantitative evidence of program effectiveness, therefore increasing their chance of receiving grant funding.

\subsection{RQ\#2. What Curricula and Pedagogical Characteristics Are Most Common among Texas EE Programs?}

\subsubsection{Number of Educational Programs $(\mathrm{n}=70)$}

The number of educational programs delivered by each organization in 2009 ranged from 3-150, with an average of 28 and a median of 19 . The number of programs differed among organization types, $H(5,68)=11.13, \mathrm{p}<.05$ (Table 1 ). Private organizations (30) had a higher number of educational programs than university organizations (15). The number of education programs reported was distorted by the interpretation of the word 'program.' The survey question stated, 'How many educational programs does your organization offer? Please provide us with the number of programs including all in-class lectures, interpretive trails, recreational programs, experiments, night hikes, lesson plans for school teachers, etc.' This was confusing for program directors because it did not specify the difference between the program itself (e.g., a curriculum unit) and the frequency in which the programs were conducted. For example, 150 programs were reported by a small state park. It is doubtful that this small park had 150 different curriculum units, more likely, they conducted 150 total programs in 2009. Future research in this area should better differentiate types of programs from frequency of programs offered. EEDOP provides a unique tool for EE by identifying specific programs and the potential impact of the discipline across a region.

\subsubsection{Number of Education Programs Conducted Outdoors $(\mathrm{n}=71)$}

A range of 1-220 outdoor educational programs are conducted, with an average of 23 and a median of 13 . Based on the medians, $72 \%$ of Texas EE programs are conducted outside. Considering that land in Texas is $94 \%$ privately owned (Texas Environmental Profiles, 2001), it is significant to know that three quarters of EE programs are being conducted in outdoor settings. Similar to the number of education programs, this result could be an overestimate due to an inaccurate interpretation of the word 'program.' A state-wide EE organization reported conducting 220 outdoor programs and 80 educational programs. It is likely that this organization reported all outdoor activities (e.g., hiking, fishing, bird watching) and not those that had an EE component. Through EEDOP, Texas could lead the nation by providing quantitative regional information on outdoor programs and outdoor initiatives, e.g. No Child Left Inside, Texas Children in Nature, and Nature Rocks.

\subsubsection{Formal/Informal Programming $(\mathrm{n}=72)$}

Twenty-seven organizations (33\%) primarily conducted formal education programs, while $38(46 \%)$ conducted mostly informal programs (Figure 3). Seven organizations reported using an equal number of formal/informal programming (3-university, 2-private, 2-federal). For example, the Lady Bird Johnson Wildflower Center (LBJWC), a university-based EE organization, incorporated both formal and informal programming within their 'Exploring the Native Plant World' curriculum (Russell, 2004). This curriculum is based on state and national learning objectives with formal, in-class activities and informal, outdoor field trips. The curricula unit 'Adaptations in the Native Plant World' focuses on natural selection, Mendelian genetics, climate, and habitats through in-class activities and a field trip to the LBJWC where the students observe plant structures and strategies for survival in various habitats.

The NEEAC (2005) has recommended that the National Office of EE create legislation that institutionalizes EE across the country to promote EE within K-12 education. The NEETF (2001) recommended that EE should extend beyond the classroom, emphasizing the importance of informal programs. Goldman et al. (2013) suggested that K-12 school systems outsource EE to informal organizations to increase students' environmental literacy and stewardship. The LBJWC provides an excellent model for incorporating both formal and informal learning opportunities into a 
single curricula unit. EEDOP provides a tool for linking formal and informal programming by providing a source of public information concerning programs like LBJWC.

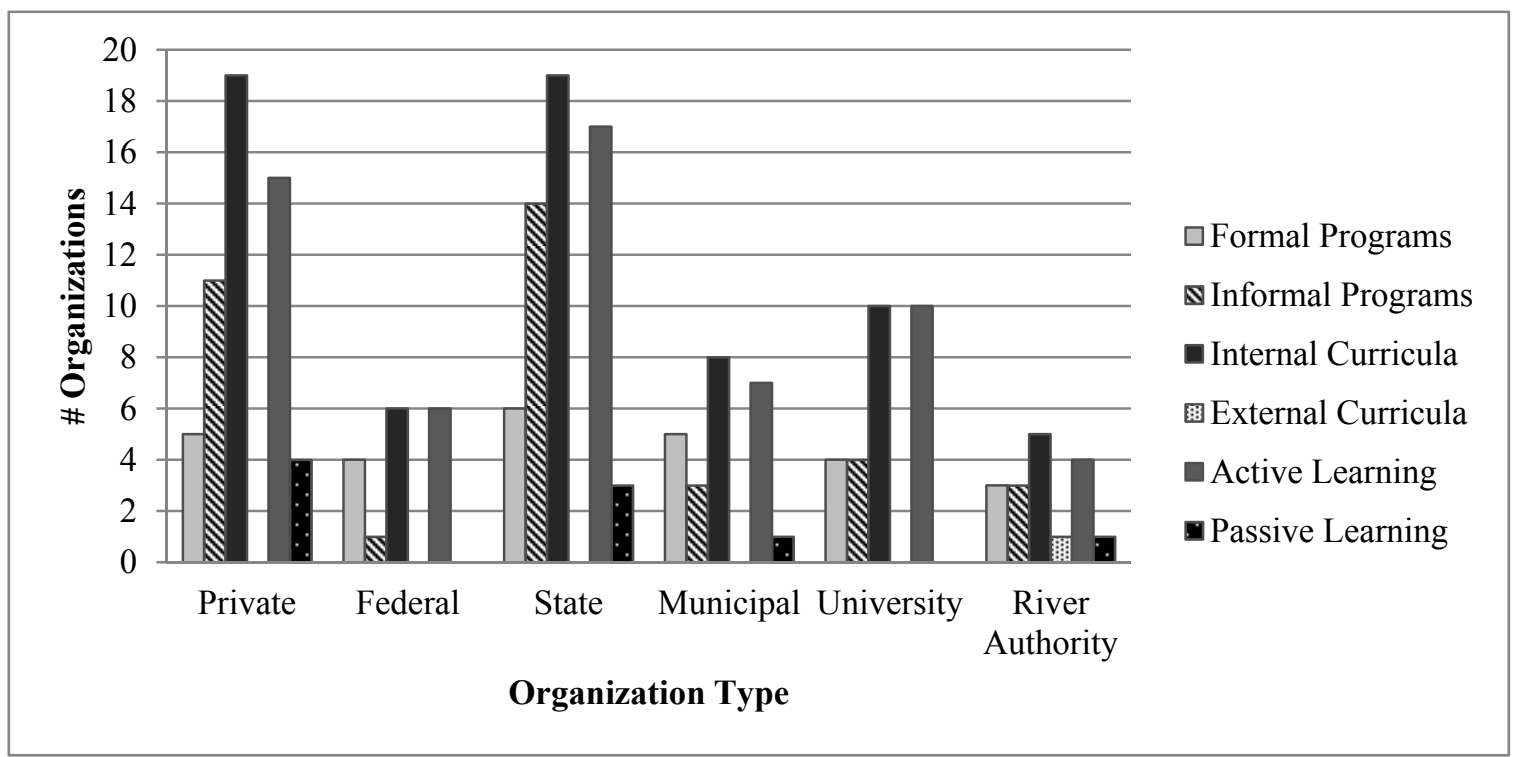

Figure 3. Distribution of Texas EE Organizations Using Formal/Informal Programming, Internal/External Curricula, and Active/Passive Learning Strategies

\subsubsection{Internally/Externally Developed Curricula $(\mathrm{n}=72)$}

Regardless of organization type (e.g., state, private), most organizations $(69,84 \%)$ primarily use curricula that were developed internally by their staff to educate visitors. One organization mainly used external curricula and two reported using an equal number of both (Figure 3). For example, The Outdoor Education Center of the Houston Independent School District used internally developed curricula that were supplemented by lessons and activities from national curricula, like Project Wild. This provides an opportunity for research between programs in different regions with different demographics. The concepts and learning activities would be similar but the audiences might be different, e.g., low socioeconomic students in Houston versus affluent students in Dallas. This strategy establishes a learning environment that is focused on local environmental issues, but is grounded in widely used curricula.

National EE curricula aligned to individual organizations' curricula provides learning experiences that can be assessed at a large scale. For example, Texas students who participate in Project Learning Tree could be compared to New York students who have had the same learning experiences. EEDOP identifies organizations that use national curricula and the demographics they serve so that comparisons can be made across organizations, regions, states, and nations.

\subsubsection{Active/Passive Learning Strategies $(\mathrm{n}=72)$}

Sixty-one (74\%) organizations primarily use active learning strategies, nine primarily used passive learning strategies, and two use equal numbers of both. All organization types (e.g., state, private) primarily focused on active learning strategies to educate their participants (Figure 3). Among the active learning strategies provided in the survey, most organizations used outdoor experiments and group discussions to engage students. Boaventura et al. (2013) suggested that outdoor experiments are important for improving youth's understanding of scientific concepts, and Michael (2006) emphasized the importance of using a variety of active learning strategies to increase student understanding. Hampden-Thompson and Bennett (2013) showed that using active learning strategies in the classroom resulted in students who had a higher motivation to learn science, were more likely to enjoy learning about science, and were interested in scientific careers.

The frequent use of active learning strategies among Texas EE practitioners suggests constructivism as the underlying learning theory. Constructivism predicts that knowledge is generated by the individual based on their experiences (Cooper 1993), and emphasizes the impact of societal influences on personal experiences and learning (NRCNA 2009). Constructivism is the most commonly cited theory in EE literature (Lisowski \& Disinger, 1992; 
Klein \& Merritt, 1994; Robertson, 1994; Ballantyne \& Packer, 1996; Lord, 1999; May, 2000; Alvarez et al., 2002; Dillon, 2003; Stauffacher et al., 2006; Lundholm et al., 2013; Wals \& Dillon, 2013); however, Robertson (1994) and Dillon (2003) stated that theories are not commonly used in the field and that a theoretical framework within EE is virtually unknown. Theories provide a critically important guide for directing high quality research and are vital to the development and advancement of all academic disciplines (Parsons 1938). EEDOP provides evidence that Texas EE programs primarily use a constructivist approach to education. Future studies could determine the affect of constructivist learning on student academic scores and determine if those scores are higher than students learning via other theories. EEDOP could be used to make those comparisons.

\subsubsection{Recreational Programming}

In Texas, the most common recreational activity used by EE organizations was hiking $(68 \%$, Similarly, $70 \%$ of organizations reported using interpretive trails as a common educational approach. The word 'interpretation,' like program, refers to a wide array of educational experiences, from signage along an unguided hiking trail to a park ranger's discussion of a historical landmark. The second most common recreational activity included water sports such as fishing, kayaking, and canoeing. Similar to hiking, it is unclear whether these recreational activities are guided or not. Most likely, recreational equipment is rented or checked-out to the visitor with no addition information on environmental topics or issues. However, this is not the case for the Texas Paddling Trails established by TPWD (2013). Each river trail has a website that describes local wildlife, ecology, historical landmarks, and gives information on stewardship, providing an informal guided experience. Recreation and outdoor experiences, especially those that are guided, provide a powerful tool for achieving educational goals and developing environmental stewards (NEETF, 2001). EEDOP could help identify the strengths of both guided and unguided interpretive programs.

\subsubsection{NAAEE Guidelines}

Twenty-eight (34\%) organizations incorporated NAAEE guidelines into EE programming, 26 (32\%) did not, and 17 (21\%) were not aware that there were national guidelines $(n=71)$. The Texas EE Partnership (2006) has recommended that Texas adopt the NAAEE guidelines as educational standards, but this partnership has no regulatory ability to institute implementation. If these guidelines are incorporated into the state learning standards it would provide professional development for both formal and informal EE practitioners and teachers, funding to implement EE programming, a certification program for teachers, a network of organizations, and information on best practices. As Texas continues to implement national guidelines into local programs, EEDOP could be used to monitor that progress.

\subsection{RQ\#3. What Are the Basic Operational Characteristics of Texas EE Programs?}

\subsubsection{Acreage $(\mathrm{n}=64)$}

The property size at which Texas organizations conduct their mission to implement EE programming ranged from 1.6 to 801163 acres with an average of 21186 and a median of 300 (Figure 4). The amount of acreage for organization type differed, $H(5,62)=20.98, \mathrm{p}<0.01$ (Table 1). State organizations (average acres $=1038$ ) had more acreage than private organizations (100 acres). Total acreage reported by 64 organizations was 1355887 which is $0.8 \%$ of Texas' land area (of 168217600 total acres, U.S. General Services Administration, 2004). This study represented a small sample of EE organizations in Texas and much of the land used for EE programming is not accounted for. By incorporating EE within the K-12 education system, more public and private land could be used to develop and grow EE programs across the state. Research shows that students who learn outdoors are healthier (Maller et al., 2008), more cooperative (Burdette, 2005), more creative (Kellert, 2005), more confident (Floriani \& Kennedy, 2008), better problem-solvers (Kellert, 2005), better performers on academic tests (Lieberman \& Hoody, 1998), and self-disciplined (Burdette, 2005). EEDOP promotes the outdoor movement by helping organizations to identify additional venues for programming. 


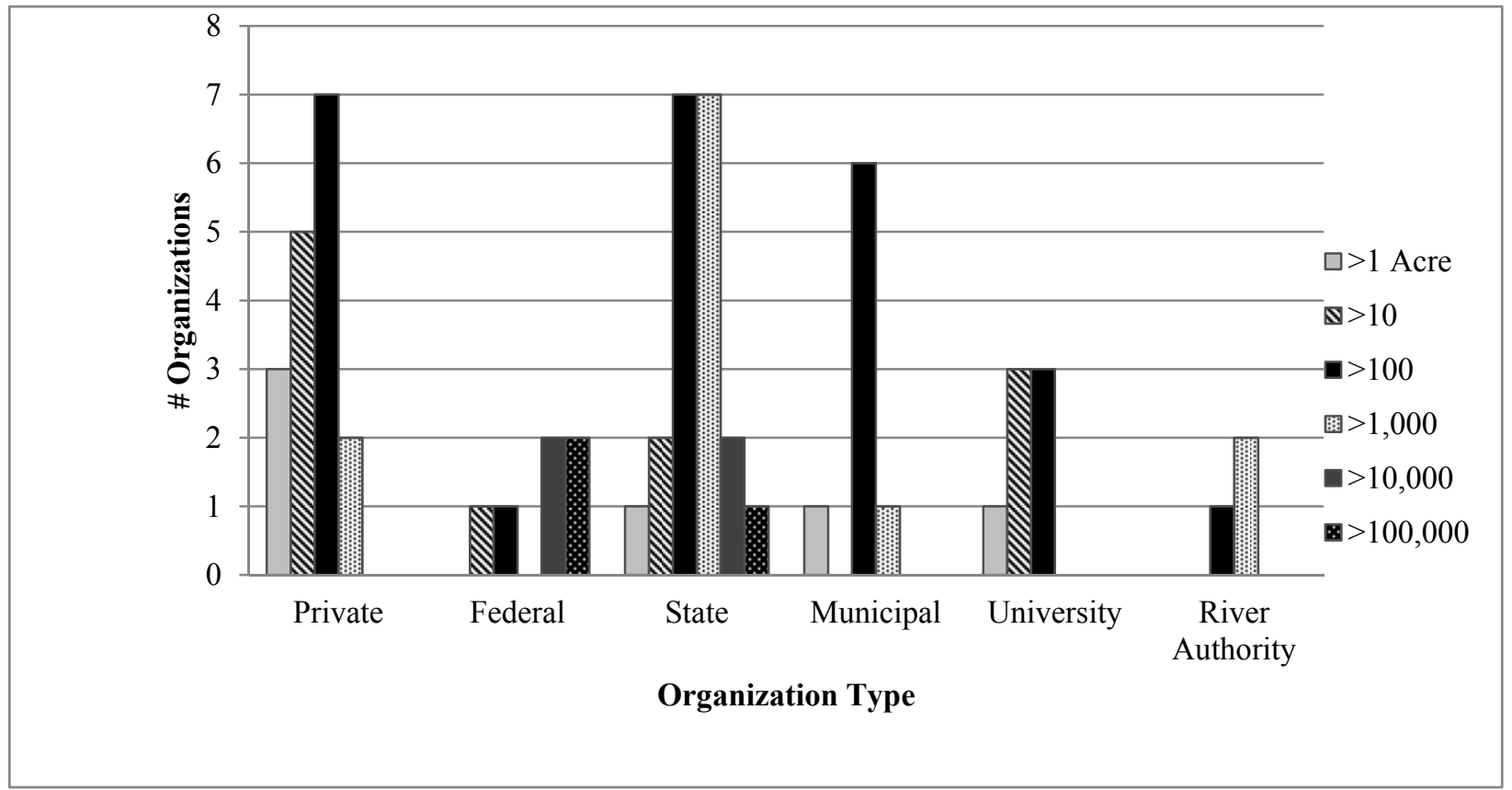

Figure 4. Acreage According to Texas EE Organization Types

\subsubsection{Educators $(\mathrm{n}=68)$}

Sixty-nine programs reported having a range of 0-45 educators, with one Boy Scout council reporting 500 educators. The average number of educators was 14 with a median of three. The number of educators for each organization type differed, $H(5,67)=12.76, \mathrm{p}<0.05$. Private organizations (11) had more educators than state organizations (2). The majority $(39,48 \%)$ of organizations employed paid educators who were not certified Texas teachers, $13(16 \%)$ employed paid educators with Texas teaching certificates, and $14(17 \%)$ primarily used volunteers. All organization types primarily employed teachers that were not certified, except municipal organizations which employed equal numbers of certified and uncertified teachers.

Because EE is not regulated by Texas, teachers are not required to be certified or have any kind of additional training. The use of mostly non-certified teachers or volunteers may relate to the abundance of informal programs (46\%) offered by EE organizations. Texas reported to have coordinated teacher in-service training for EE in 1995 and 1998 (Kirk et al., 1997; Ruskey et al., 2001); however, a web search could not verify that this was ever in practice. The NEEAC (1996) suggests that teacher training is one of the most cost effective initiatives for enhancing EE nationwide. Other states, e.g. Washington, provide evidence for the effectiveness of integrating EE into the formal curriculum and teacher training by showing improved STEM scores of students (Bergeson et al., 2007). EEDOP could substantiate this claim.

\subsection{RQ\#4. Are Texas EE Programs Being Assessed? How? (n=72)}

The majority $(40,56 \%)$ of organizations assessed some or all of their educational programs. Fifteen organizations assessed all their programs while 17 did not assess any. Of the organizations that assessed their programs, observational techniques or questionnaires were used most frequently. Nine organizations kept track of their K-12 visitors' state standardized test scores. Mitchell Lake Audubon Center assessed all their educational programs using observations, questionnaires, and anecdotal evidence. Although these can be powerful tools for determining how a participant feels about a program, other forms of assessment may better determine if the educational goals of a program are being met.

Assessment is an essential tool for organizational performance, effectiveness, and program growth (Niedermeyer, 1992; NEEAC, 2005; Carleton-Hug \& Hug, 2010). The NEEAC (2005) argued for the development of a cumulative body of information in the field, while Carleton-Hug and Hug (2010) suggested the use of free online publications from NAAEE to aid the evaluative process (e.g., Using a Logic Model to Review and Analyze an Environmental Education Program, Marcinkowski, 2004). EEDOP could provide a tool for recording and analyzing assessment data from multiple organizations so that regional trends in effectiveness can be identified. 


\subsection{RQ\#5. Are There Relationships among Program Characteristics?}

Relationships exist among many program characteristics (Table 2). This paper represents a foundational study that identifies trends, while future studies using EEDOP could identify confounding variables of underlying relationships (e.g. multivariate analyses). Below we discuss the following relationships: visitation/funding, visitation/programs, and funding/acreage.

Table 2. Relationships among Program Characteristics

\begin{tabular}{|c|c|c|c|c|c|c|}
\hline Characteristic & $\begin{array}{c}\text { Visitation } \\
\text { Rate }\end{array}$ & Funding & $\begin{array}{l}\text { Education } \\
\text { Programs }\end{array}$ & $\begin{array}{l}\text { Outdoor } \\
\text { Programs }\end{array}$ & Acreage & Educators \\
\hline $\begin{array}{l}\text { Visitation } \\
\text { Rate }\end{array}$ & --- & & & & & \\
\hline Funding & $\begin{array}{c}r s(60)=0.38, \\
\mathrm{p}<.01\end{array}$ & --- & & & & \\
\hline $\begin{array}{l}\text { Education } \\
\text { Programs }\end{array}$ & $\begin{array}{c}r s(67)=0.48, \\
\mathrm{p}<.001\end{array}$ & NS & --- & & & \\
\hline $\begin{array}{l}\text { Outdoor } \\
\text { Programs }\end{array}$ & $\begin{array}{c}r s(68)=0.31, \\
\mathrm{p}<.01\end{array}$ & NS & $\begin{array}{c}r s(70)=0.80 \\
\mathrm{p}<.001\end{array}$ & --- & & \\
\hline Acreage & NS & $\begin{array}{c}r s(53)=-0.33 \\
\mathrm{p}<.05\end{array}$ & NS & NS & --- & \\
\hline Educators & NS & $\begin{array}{c}r s(54)=0.37 \\
\mathrm{p}<.01\end{array}$ & $\begin{array}{c}r s(64)=0.34 \\
\mathrm{p}<.01\end{array}$ & $\begin{array}{c}r s(65)=0.33 \\
\mathrm{p}<.01\end{array}$ & NS & --- \\
\hline
\end{tabular}

NS - Not Significant

\subsubsection{Annual Visitation and Funding}

Annual visitation was positively correlated to funding, $r s(60)=0.38, \mathrm{p}<.01$. More funding allows for high quality materials, highly trained educators, and a variety of programs likely to attract more visitors. Highly funded organizations can also hire professionals to improve advertising initiatives and increase annual visitation. On the other hand, annual visitation could be the independent variable within this relationship. By having more people participate in an organization's programs, it might be able to acquire more funding. For example, if a national park can show that annual visitation have steadily increased over time, the National Park Service may be willing to increase their budget for education.

\subsubsection{Annual visitation and Education Programs}

Annual visitation was positively correlated with the number of educational programs, $r s(67)=0.48, \mathrm{p}<.001$. Increasing the number of programs could lead to higher annual visitation or vice versa. This relationship is likely mediated by funding, attraction features, the organization's mission, or a combination thereof. Funding has the ability to support quality programs and meet the education and recreation needs of many visitors. Attraction features, such as a scenic area or an endangered bird species could affect annual visitation and programs. People hear about these features and visit the organization; once there, the visitors experience quality programs which cause them to return. Lastly, the relationship between visitation and programs could be affected by an organization's mission and the population they want to serve. For example, in 2009 the Fort Worth Museum of Science and History served over 650000 people in a large city using 30 different programs. On the other hand, Hutchinson County Historical Museum served 5000 visitors in a small rural area with 7 educational programs. The missions of these two organizations help determine the structure and capacity of their education initiatives.

\subsubsection{Funding and Acreage}

Acreage was negatively correlated with funding, $r s(53)=-0.33, \mathrm{p}<.05$. Organization types differed in funding and acreage suggesting that underlying factors influence this relationship, e.g., legislation. In 1995, Texas residents voted to support the state park system by enacting a sporting goods tax; however, the majority of funds generated from the tax go into a general account (General Appropriations Act). Another form of raising funds is to require entrance fees, 
but most organizations' operating budgets are spent primarily on salaries and maintenance, leaving little for education programming. The Texas park system has ample land for conducting outdoor programs ( $\sim 1000$ acres each), but are not well funded for education $(\sim \$ 1 \mathrm{~K} /$ year $)$. Private organizations, on the other hand, are funded through individual donors/grants and therefore allocate more money to programming ( $\sim \$ 120 \mathrm{~K} / \mathrm{year})$, but have less land available for outdoor programs ( 100 acres).

\subsection{Recommendations}

Each EE organization in Texas represents an 'island' in which people can learn about environmental topics and participate in nature activities. Given that the climate is warming, ecosystems are changing, the human population is growing, and our natural resources are becoming more limited (MEA, 2005; IPCC, 2013), these islands play a crucial role in the development of environmentally literate citizens who can better identify environmental problems, develop solutions, and implement sustainable practices. Texas is developing a supportive structure for EE through events like the Environmental Literacy Summit, and networks like Texas Children in Nature. These efforts are increasing EE state-wide; however, with only $6-20 \%$ of Texas residents and $13-47 \%$ of K-12 students participating in $\mathrm{EE}$, more can be done to improve the quantity and quality of EE in the state. Based upon this analysis, the results of Kirk et al. (1997) and Ruskey et al. (2001), and the literature (NEEAC, 1996, 2005; NEETF, 2001; Coyle, 2005), we make recommendations for improving EE in Texas (Table 3).

Table 3. Recommendations and Associated Benefits for Improving EE in Texas

\begin{tabular}{|c|c|}
\hline Suggestion & Benefit \\
\hline \multicolumn{2}{|l|}{ Individual Organizations } \\
\hline $\begin{array}{l}\text { Increase Visitation Rates } \\
\text { through quality programming }\end{array}$ & $\begin{array}{l}\text { - Increasing visitation rates could increase the number of } \\
\text { environmental stewards in Texas }\end{array}$ \\
\hline $\begin{array}{l}\quad \text { Use focus groups/surveys to } \\
\text { identify/address barriers for certain } \\
\text { demographics }\end{array}$ & $\begin{array}{l}\text { - People of all races, genders, and socio-economic groupings will } \\
\text { benefit from EE }\end{array}$ \\
\hline \multirow[t]{2}{*}{$\begin{array}{l}\text { Implement national EE } \\
\text { curricula and assess students }\end{array}$} & $\begin{array}{l}\text { - Determine what pedagogical strategies help different } \\
\text { demographic groups learn }\end{array}$ \\
\hline & $\begin{array}{l}\text { - Provide data for comparisons across different organization } \\
\text { types to see if students have similar outcomes }\end{array}$ \\
\hline $\begin{array}{l}\text { Design and implement more } \\
\text { outdoor EE programs }\end{array}$ & $\begin{array}{l}\text { Studies show that being outdoors improves health, confidence, } \\
\text { self-esteem, creativity, cooperation, problem-solving, self } \\
\text { discipline, and academic scores }\end{array}$ \\
\hline $\begin{array}{l}\text { Advertise guided and } \\
\text { unguided EE experiences }\end{array}$ & $\begin{array}{l}\text { - This will help visitors to choose the type of program they are } \\
\text { interested in and therefore increase visitation rates }\end{array}$ \\
\hline $\begin{array}{l}\text { Advertise biotic, scenic, and } \\
\text { historic features }\end{array}$ & - Increased visitation rates and sense of place \\
\hline \multirow[t]{3}{*}{$\begin{array}{l}\text { Develop high quality } \\
\text { instruments for assessment }\end{array}$} & $\begin{array}{l}\text { - A few well developed assessments can indicate if learning } \\
\text { outcomes are being met }\end{array}$ \\
\hline & $\begin{array}{l}\text { - Assessments can be used to determine overall effectiveness and } \\
\text { growth of organizations }\end{array}$ \\
\hline & - Add to a body of information on best practices \\
\hline \multicolumn{2}{|l|}{ Regional } \\
\hline $\begin{array}{l}\text { Develop Children in Nature } \\
\text { initiatives in your region }\end{array}$ & $\begin{array}{l}\text { Increase nature experiences among youth which may increase } \\
\text { environmental literacy/stewardship }\end{array}$ \\
\hline \multirow[t]{2}{*}{ Develop regional EE offices } & $\begin{array}{l}\text { Provide individual organizations with information on best } \\
\text { practices, curricula, etc. }\end{array}$ \\
\hline & $\begin{array}{l}\text { - Be an intermediary between individual EE organizations and } \\
\text { state organizations like TAEE, TEEAC, TEEP, TEA }\end{array}$ \\
\hline
\end{tabular}




\begin{tabular}{lll}
\hline State-wide & & \\
\hline Incorporate EE into TEA & - & Improve teacher training \\
education standards & - & Improve EE material quality \\
& - & Provide an avenue for assessment \\
& - & Institute state/regional offices for EE \\
Develop state EE offices & - & Provide individual organizations with information on best \\
& & practices, curricula, etc \\
& - & Be an intermediary between individual EE organizations and \\
& & state organizations like TAEE, TEEAC, TEEP, TEA \\
Developing funding programs & - & Provide yearly grants \\
& - & Improve program quality by allowing for better materials and \\
& & trained educators \\
Incorporate EE into & - & This is one of the most cost effective and efficient methods to \\
pre-service and in-service teacher & & enhance EE \\
training & - & Better trained educators
\end{tabular}

TEA - Texas Education Agency, TAEE - Texas Association for Environmental Education, TEEAC - Texas Environmental Education Advisory Council, TEEP - Texas Environmental Education Partnership

For EEDOP to be effective as a transformative tool in EE, it must remain updated, both in terms of questions asked and information received. For example, questions regarding the number of programs should be written more clearly so that more accurate responses are collected. Even though we received a $35 \%$ response rate, we know information is lacking because not all organization types were well represented. Only nine municipal organizations responded to the survey, and that number is proportionally low because many cities have a Parks and Recreation department that implements EE. EEDOP can be updated with time so that it provides a structural framework which can be used to answer functional questions for improving EE.

Once EEDOP has been implemented in multiple regions and we have the data to ask and answer large-scale EE questions, the database can be upgraded from a simple data management system to a more sophisticated knowledge management system known as a knowledgebase. Knowledge management is a process of gathering, evaluating, distributing, and using knowledge (Davenport \& Prusak, 1998; Ponzi \& Koenig, 2002). A knowledgebase is a system which maintains knowledge of a particular domain (Dalal, 1988) and incorporates artificial intelligence algorithms that can allow complex and holistic analysis of the data (Desharnais et al., 2002). Databases are static whereas knowledgebases are dynamic. For example, the freely accessible DAVID knowledgebase (Database for Annotation, Visualization, and Integrated Discovery) is an online bioinformatics resource designed to condense large databases of gene identifiers into clusters of related genes that are biologically meaningful (Huang et al., 2007; Sherman et al., 2007). This knowledgebase is different from a database because it uses sophisticated algorithms to annotate gene clusters which can help researchers to understand biology at a larger scale (Huang et al., 2007). By applying a knowledgebase approach to EE, we can focus on big-picture issues, like learning theories and functional relationships of EE organization characteristics, rather than simply listing the attributes of organizations within a particular region.

\section{Acknowledgements}

We want to express our gratitude to all the environmental education practitioners who participated in this study. Thanks to Cathy Eckert, Nancy Heron, and Zack Thomas, for their assistance with this project. Lastly, we appreciate the constructive feedback provided by: Ximena Bernal, Susan Duncan, Debbie Lloyd, Mark Wallace, and John Zak.

\section{References}

Alvarez, P., Fuente E.I., Perales J., \& Garcia J. (2002). Analysis of a quasi-experimental design based on environmental problem solving for the initial training of future teachers of environmental education. Journal of Environmental Education, 33(2), 19-21. https://doi.org/10.1080/00958960209600804

Arizona Association for Environmental Education. (2010). AAEE Resource Database. Retrieved May 30, 2013 from: 
http://www.arizonaee.org.

Baker, K.S., Benson B.J., Henshaw D.L., Blodgett D., Porter J.H., \& Stafford S.G. (2000). Evolution of a multisite network information system: the LETR information management paradigm. BioScience. 50(11), 963-978. https://doi.org/10.1641/0006-3568(2000)050[0963:EOAMNI]2.0.CO;2

Ballantyne, R.R., \& Packer J.M. (1996). Teaching and learning in environmental education: developing environmental conceptions. Journal of Environmental Education, 27(2), 25-32. https://doi.org/10.1080/00958964.1996.9941455

Becerra-Fernandez, I., \& Leidner D. (2008). On knowledge, knowledge management, and knowledge management systems: an introduction. In I. Becerra-Fernandez, D. Leidner. M.E. Sharp (eds.), Knowledge Management: An Evolutionary View. Inc: Armonk, NY.

Bergeson, T., Davidson, C., \& McGuigan C. (2007). Environmental Education Report: empirical evidence, exemplary models, and recommendations on the impacts of environmental education of K-12 students. Office of Superintendent of Public Instruction. Olympia, WA. Retrieved from http://www.k12.wa.us/EnvironmentSustainability/pubdocs/EEReport.pdf

Boaventura, D., Faria C., Chagas I., \& Galva C. (2013). Promoting Science Outdoor Activities for Elementary School Children: Contributions from a research laboratory. International Journal of Science Education, 35(5), 796-814. https://doi.org/10.1080/09500693.2011.583292

Burdette, H.L., \& Whitaker R.C. (2005). Resurrecting Free Play in Young Children: Looking Beyond Fitness and Fatness to Attention, Affiliation and Affect. Arch Pediatr Adolesc Med., 159(1), 46-50. https://doi.org/10.1001/archpedi.159.1.46

Carleton-Hug, A., \& Hug J.W. (2010). Challenges and opportunities for evaluating environmental education programs. Evaluation and Program Planning, 33(2), 159-164. https://doi.org/10.1016/j.evalprogplan.2009.07.005

Chavez, D., \& Herron N. (2000). Directory of Texas Environmental Education \& Interpretive Facilities. Texas Association for Environmental Education. Texas Parks and Wildlife.

Cooper, P. A. (1993). Paradigm shifts in designed instruction: from behaviorism to cognitivism to constructivism. Educational Technology, 12-19.

Coyle, K. (2005). Environmental Literacy in America. The National Environmental Education and Training Foundation: Washington, DC.

Dalal, M. (1988). Investigations into a theory of knowledge base revision: preliminary report. Proceedings of the $7^{\text {th }}$ National Conference on Artificial Intelligence, 88, 475-479.

Davenport, T., \& Prusak L. (1998). Working knowledge: how organizations manage what they know. Boston, MA: Harvard Business School Press.

Desharnais, J-M., Abran A., Mayers A., Buglione L., \& Bevo V. (2002). Knowledge modeling for the design of a KBS in the functional size measurement domain. In E. Damiani, R.J. Howlett, L.C. Jain, N. Ichalkaranje (eds.), In Knowledge-Based Intelligent Information Engineering Systems \& Allied Technologies. IOS Press: Amsterdam, The Netherlands.

Dillon, J. (2003). On learners and learning in environmental education: missing theories, ignored communities. Environmental Education Research, 9(2), 215-226. https://doi.org/10.1080/13504620303480

Environmental Education in Alabama. (n.d.). EE Resource Types - Definitions and Examples. Find Resources. Retrieved May 30, 2013 from: http://eeinalabama.org

Floriani, V., \& Kennedy C. (2008). Promotion of physical activity in children. Current Opinion in Pediatrics, 20(1), 90-95. https://doi.org/10.1097/MOP.0b013e3282f3d9f9

Franklin, J.F., Bledsoe C.S., \& Callahan J.T. (1990). Contributions of the Long-Term Ecological Research Program: an expanded network of scientists, sites, and programs can provide crucial comparative analyses. BioScience. 40(7), 509-523. https://doi.org/10.2307/1311319

Fuller, S.S., Revere D., Bugni P.F., \& Martin G.M. (2004). A knowledgebase system to enhance scientific discovery: Telemakus. Biomedical Digital Libraries, 1(2). https://doi.org/10.1186/1742-5581-1-2

Goldman, D., Assaraf, O.B.Z., \& Shaharabani D. (2013). Conceptions of Biology and Approaches to Learning of 
First Year Biology Students: Introducing a technique for tracking changes in learner profiles over time. International Journal of Science Education, 35(3), 515-545. https://doi.org/10.1080/09500693.2012.749545

Gramann, J.H. (2003). Visitation Forecasting and Predicting Use of NPS Parks and Visitor Centers: Focus Group Report. National Park Service Social Science Program. Washington, DC.

Hampden-Thompson, G., \& Bennett J. (2013). Science teaching and learning activities and student's engagement in science. International Journal of Science Education, 35(8), 1325-1343. https://doi.org/10.1080/09500693.2011.608093

Huang, D.W., Sherman, B.T., Tan Q., Collins J.R., Alvord W.G., Roayaei J., \& Stephens R., et al. (2007). The DAVID Gene Functional Classification Tool: a novel biological module-centric algorithm to functionally analyze large gene lists. Genome Biology, 8(9). https://doi.org/10.1186/gb-2007-8-9-r183

Illinois Environmental Education Database. (2003). Environmental Literacy for Illinois. Retrieved May 30, 2013 from http://www.illinoisee.org/

Inchausti, P., \& Halley J. (2001). Investigating long-term ecological variability using the Global Population Dynamics Database. Science, 293, 655-657. https://doi.org/10.1126/science.293.5530.655

Intergovernmental Panel on Climate Change (IPCC). (2013). Climate Change 2013, the Physical Science Basis. Cambridge University Press: New York, NY.

Kellert, Stephen R. (2005). Nature and Childhood Development In Building for Life: Designing and Understanding the Human-Nature Connection. Washington, D.C.: Island Press.

Kirk, M., R., \& Wilke, A. Ruskey. (1997). A survey of the status of state-level environmental education in the United States. The Journal of Environmental Education, 29(1), 9-16. https://doi.org/10.1080/00958969709599102

Klein, E.S., \& Merritt, E. (1994). Environmental education as a model for constructivist teaching. Journal of Environmental Education, 25(3), 14-21. https://doi.org/10.1080/00958964.1994.9941953

Lal, A., Lash A.E., Altschul, S.F., Velculescu V., Zhang L., McLendon R.E., \& Marra M.A., et al. (1999). A public database for gene expression in human cancers. Cancer Research, 59, 5403-5407.

Lieberman, G.A., \& Hoody L.L. (1998). Closing the achievement gap: using the environment as an integrating context for learning. State Education and Environment Roundtable: San Diego, CA.

Lisowski, M., \& Disinger J.F. (1992). The effect of field-based instruction on students' understanding of ecological concepts. Journal of Environmental Education, 23(1), 19-23. https://doi.org/10.1080/00958964.1991.9943065

Lord, T.R. (1999). A comparison between traditional and constructivist teaching in environmental science. Journal of Environmental Education, 30(3), 22-28. https://doi.org/10.1080/00958969909601874

Lundholm, C., Hopwood N., \& Rickinson M. (2013). Environmental learning: insights from research into the student experience. In R.B. Stevenson, M. Brody, J. Dillon, A.E.J. Wals (eds.), International Handbook of Research on Environmental Education. Routledge: New York, NY. https://doi.org/10.4324/9780203813331.ch25

Maller, C., Townsend M., St.Leger L., Henderson-Wilson, C., Pryor A., Prosser L., \& Moore M. (2008). Healthy Parks, healthy people: the health benefits of contact with nature in a park context: A review of relevant literature. School of Health and Social Development. Deakin University and Parks Victoria.

Marcinkowski, T.C. (2004). Using a logic model to review and analyze an environmental education programs. North American Association for Environmental Education (NAAEE).

Mari, A. (2005). Importance of databases in experimental and clinical allergology. Int Arch Allergy Immunol, 138, 88-96. https://doi.org/10.1159/000087848

May, T.S. (2000). Elements of Success in environmental education through practicioner eyes. Journal of Environmental Education, 31(3), 4-11. https://doi.org/10.1080/00958960009598639

Michael, J. (2006). Where's the evidence that active learning works? Advan in Physiol Edu, 30, 159-167. https://doi.org/10.1152/advan.00053.2006

Millennium Ecosystem Assessment (MEA). (2005). Ecosystems and Human Well-Being: Synthesis. Island Press, Washington, DC.

National Atlas. (2013). Profile of the People and Land of the United States - Area. Retrieved from 
$\mathrm{http} / / /$ nationalatlas.gov/articles/mapping/a_general.html\#one

National Center for Education Statistics. (n.d.). Common Core of Data. Retrieved September 25, 2013. From http://nces.ed.gov/ccd/

National Environmental Education Advisory Council (NEEAC). (1996). Report assessing environmental education in the United States and the implementation of the National Environmental Education Act of 1990. US Environmental Protection Agency Environmental Education Division. Washington DC.

National Environmental Education Advisory Council (NEEAC). (2005). Setting the standard, measuring results, celebrating success: a report to congress on the status of environmental education in the United States. US Environmental Protection Agency Environmental Education Division. Washington DC.

National Environmental Education and Training Partnership (NEEFT). (2001). Lessons from the environment: why 95\% of adult Americans endorse environmental education. Roper Starch Worldwide. Retrieved from http://www.neefusa.org/pdf/roper/Roper2000.pdf

National Research Council of the National Academies (NRCNA). (2009). Learning science in informal environments: people, places, and pursuits. The National Academies Press: Washington, D.C.

Niedermeyer, F.C. (1992). A checklist for reviewing environmental education programs. Journal of Environmental Education, 23(2), 46-50. https://doi.org/10.1080/00958964.1992.9942795

North American Association for Environmental Education (NAAEE). (2007). Correlations rubric for national core competencies for professional environmental educators seeking certification and fundamentals of Environmental Education. Retrieved from http://old.naaee.org/programs-and-initiatives/fee-and-core-competencies-correlations-rubric.pdf

North Carolina Environmental Education. n.d.. Find Resources. Retrieved May 30, 2013 from http://web.eenorthcarolina.org

Parsons, T. (1938). The role of theory in social research. American Sociological Review, 3(1), 13-20. https://doi.org/10.2307/2083507

Ponzi, L., \& Koenig M. (2002). Knowledge management: another management fad? Information Research, 8(1).

Robertson, A. (1994). Toward constructivist research in environmental education. Journal of Environmental Education, 25(2), 21-31. https://doi.org/10.1080/00958964.1994.9941948

Ruskey, A., Wilke R., \& Beasley T. (2001). A survey of the status of state-level environmental education in the United States - 1998 update. The Journal of Environmental Education, 32(3), 4-14. https://doi.org/10.1080/00958960109599139

Russell, M. (2004). Exploring the Native Plant World: A Life Science Curriculum. Lady Bird Johnson Wildflower Center, Austin, TX.

Sherman, B.T., Huang D.W., Tan Q., Guo Y., Bour S., Liu D., \& Stephens R., et al. (2007). DAVID Knowledgebase: a gene-centered database integrating heterogeneous gene annotation resources to facilitate high-throughput gene functional analysis. BMC Bioinformatics, 8, 426. https://doi.org/10.1186/1471-2105-8-426

Siegel, S. (1957). Nonparametric Statistics. The American Statistician, 11(3), 13-19.

Stapp, W.B, et al. (1969). The Concept of Environmental Education. The Journal of Environmental Education, 1(1), 30-31.

Stauffacher, M., Walter A.I., Lang D.J., Wiek A., \& Scholz R.W. (2006). Learning to research environmental problems from a functional socio-cultural constructivism perspective. International Journal of Sustainability in Higher Education, 7(3), 252-275. https://doi.org/10.1108/14676370610677838

Stein, B.A. (2002). State of the Union: Ranking America's Biodiversity. NatureServe. Arlington, VA. Retrieved from http://www.natureserve.org/library/stateofunions.pdf

Texas Education Agency (TEA) (2013). Texas Essential Knowledge and Skills. Retrieved from http://www.tea.state.tx.us/index2.aspx?id=6148

Texas Environmental Education Partnership. (2006). Texas Environmental Education Mater Plan: A State-wide Cooperative Project. Retrieved from http://www.texaseepartners.org/about/documents/TEEPMasterPlan06.pdf

Texas Environmental Profiles. (2001). Public Lands and Public Recreation. Retrieved from 
http://www.texasep.org/html/lnd/lnd_5pub.html

Texas Parks and Wildlife Department. (2013). Texas Paddling Trails. Retrieved from http://www.tpwd.state.tx.us/fishboat/boat/paddlingtrails/

Texas State Data Center. (2012). Projections of the population of Texas and counties in Texas by Age, Sex and Race/Ethnicity for 2010-2050. The Office of the State Demographer. Retrieved from http:/txsdc.utsa.edu/Data/TPEPP/Projections/Methodology.pdf

U.S. Census Bureau. (2010). 2010 Census Data: Texas. Retrieved from http://2010.census.gov/2010census/data/

U.S. Census Bureau. (2010). Table 14. State Population - Rank, Percent Change, and Population Density: 1980-2010. Retrieved from http://www.census.gov/compendia/statab/2012/tables/12s0014.pdf

U.S. Department of Education. (2013). The Database of Accredited Postsecondary Institutions and Programs. Retrieved from http://ope.ed.gov/accreditation/

U.S. General Services Administration. (2004). Federal Real Property Profile. Retrieved from http://www.gsa.gov/gsa/cm_attachments/GSA_DOCUMENT/Annual\%20Report\%20\%20FY2004\%20Final_R2 M-n11_0Z5RDZ-i34K-pR.pdf

Wals, A.E.J., \& Dillon J. (2013). Conventional and emerging learning theories: implications and choices for educational researchers with a planetary consciousness. In R.B. Stevenson, M. Brody, J. Dillon, A.E.J. Wals (eds.), International Handbook of Research on Environmental Education. Routledge: New York, NY. https://doi.org/10.4324/9780203813331.ch26 